\title{
Mindre klaging, takk!
}

\section{Er det noe jeg har lært, er det at vi bør være evig takknemlig for de norske legene og det norske helsevesenet.}

Noen ganger tenker jeg at vi nordmenn klager fælt på legene våre. På hvor lenge vi må sitte på venterommet og hvor arrogante og lite omsorgsfulle de er. Og at vi er nervøse for å komme med for mange problemer på en gang, fordi vi ikke får nok tid før vi måkes ut igjen. På at de ikke er enige med oss. Eller ikke kan nok om akkurat det vi trenger at de kan nok om.

Jeg har selv klaget på opptil flere av punktene over. Jeg har nemlig hatt noen helseplager som det har tatt både tid og mange lege- og sykehusbesøk å få rett diagnose og behandling for. Ikke alt er like enkelt å finne ut av, og underveis kan man bli både frustrert og ja, klagete.

For all del: Sunn kritikk er noe alle yrkesgrupper og systemer kan tjene på. Og vi som pasienter får tips gjennom venner når vi diskuterer erfaringer. Slik fant jeg fastlegen jeg hadde i Oslo: en robust, «no nonsense»-dame av Gro Harlem Brundtland-støpning. Hun var gull verdt.

Kanskje hadde jeg ikke hengt meg opp i denne klagekulturen om det ikke var for en helt konkret personlig erfaring: Jeg utvandret til Tsjekkia. Det som brått skjedde, var at jeg sto utenfor helsesystemet. Ikke fordi Tsjekkia mangler et, men fordi jeg havnet i gruppen EØS-borgere i fri flyt uten tilgang til et statssponset helsevesen. Riktignok har jeg en helseforsikring, men den dekker bare akutte tilfeller. Blir jeg overkjørt av en bil, vil et tsjekkisk sykehus ta hånd om meg. Får jeg en akutt sykdom, vil jeg få behandling Men utover det må jeg selv punge ut.

Hvis man aldri blir syk, er det selvsagt ikke et problem. Men det blir man jo gjerne. Og igjen, ikke alle sykdommer er like enkle og selvforklarende. Resultatet er at jeg har gått drastisk mindre til lege. Mens nye helseplager har sneket seg inn. Hva gjør man når man begynner å utvikle natthoste hver vår? Jo, man oppsøker apoteket og ber om noe som i hvert fall kan lindre litt. Når slår man fast at vinterforkjølelsen har vart for lenge, og det er på tide å oppsøke hjelp? Jeg forbandt ikke symptomene med hverandre, og med dramatisk evne begynte jeg å tenke at dette nok var begynnelsen på slutten. Jeg ble jo bare sykere og sykere, med flere og flere plager. Tankene gikk til alt fra aids til organsvikt. For hvem i huleste er forkjølt et halvt år i strekk? Og det var ikke bare litt, liksom. Jeg snørret meg igjennom minst en rull dopapir om dagen, øynene rant, og kroppen verket. Jeg var kanskje ikke akutt syk, men jeg var liksom heller aldri frisk lenger.

Jeg mistenkte at det ville kreve en mengde prøver og utredninger å finne ut av elendigheten, akkurat slik det hadde gjort med matallergien mens jeg bodde i Norge. Et kort legebesøk her med noen standard blodprøver koster meg et par tusenlapper hver gang.

Så hva gjør man? Jeg grep til Facebook, og venner og bekjente slo nokså unisont fast at dette garantert var allergi, og at man ikke trengte full utredning for å få medisiner for det.

Jeg antar at en god del leger vil steile over at man bruker Facebook til å diagnostisere seg selv, som en del rasende kommentatorer på min side gjorde. Jeg mistenker at ingen av dem har erfaring med ikke enkelt og nesten gratis å kunne gripe til fastlegen, enn si eksperter man blir henvist til.

Etter en lett undersøkelse og samtale slo også legen fast at det var allergi. Jeg fikk medisiner og er sånn passe mye bedre. Hadde disse symptomene dukket opp mens jeg bodde i Norge, hadde jeg gått til lege for lenge siden. Jeg ville også kanskje fått vite hva jeg reagerer på. Jeg ville i hvert fall ha bedt om videre utredning og kanskje justert medisinene eller livsstilen etter det, slik at jeg kunne ha blitt enda litt bedre.

Jeg håper for alt $\mathrm{i}$ verden at jeg slipper å få nye helseplager. Bekymringsnivået blir nemlig et helt annet når du må betale for alt selv.

Det fire år i utlendighet har lært meg, er altså at jeg alt i alt er himla fornøyd med både norske leger og det norske helsesystemet. Det er ikke perfekt. Men det er utrolig mye mer perfekt enn å stå utenfor.

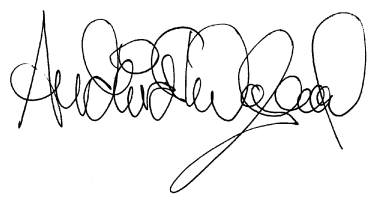

